\title{
Teaching Strategy and Learning Model Using Practice Method
}

\author{
Khudriyah \\ Dosen Sekolah Tinggi Ilmu Tarbiyah Al Urwatul Wutsqo Jombang, Indonesia \\ Email: azkiabilqis@gmail.com
}

\begin{abstract}
This research is done because of the phenomenon in some teaching and learning process happened at STIT al Urwatul Wutsqo. The researcher found that most of students could not practice of teaching using some methods, strategy or models. They practiced the teaching using lecturing method, mean while they are prepared to be professional teacher. The lecturing method is not bad, but it has many disadvantages, one of them is boring method, especially when the teacher cannot organize it well, the students will be bored easily. This research is aimed to know how practice method is effective to prepare the students to be professional teacher. The design of the research is qualitative descriptive, observation, questionnaire interview and documentation, were as instruments. The result is the practice method is very effective, such as; most of students were actively involved in the teaching and learning process. Most of students chose positive answer which supported the implementation of practice method, the students were able to gain good and high score, and they showed their positive responses to the teaching using practice method.
\end{abstract}

Keywords: Strategy and Learning Model, Practice Method 


\section{Background of the Study}

Teaching and learning strategies can include all activities of the whole class, either in a group or an individual. It is used to accommodate the student's different abilities, skills, learning rates and styles that allow them to participate and achieve some degree of success. It is commonly happened that every class has different character of students, they consists on high, middle, and low level. That is why teaching and learning strategy is needed based on their characteristic.

The importance of teaching and learning strategies is making the instructors are easier to implement a variety of teaching methods and techniques. It is able to help students take more responsibility for their own learning and enhancing the process of teaching for learning. Because the main purpose of learning is student success.

According to Richards and Platt, learning strategies are behavior and thoughts used by learners during learning in order to get something better and help them understand, learn, or remember new information.(Richards, J. And John Platt, 1922, p.209) This concurs with O'Malley and Chamot, as they said "Learning strategies as "special thoughts or behaviors used by individuals to help them to be comprehend, learn, or retain new information. (O'Malley, J. M. \& Chamot, A. U, 1990) It can be said that strategy is very important to determine whether or not the learning will be succeed, because it is a special ways of processing information that improve comprehension, learning, or retention of the information.
The environment interaction can influence the students' motivation in learning. When they are in the classroom, the teachers can be one of the environments. Besides, teachers are one determinant of student success, so they must be their pioneer. This reason makes them must be creative teachers. And having good strategy in teaching is one of the teachers' requirements.

The content of teaching will necessarily make some strategies more suitable than others. Strategy is a general pattern of series activities that should be done to achieve certain goals. It is a plan or an idea. So the strategy must be drawn up for specific purpose to achieve the goal.(Wina Sanjaya, 2006, p.99) It can be said strategy is used as guidelines, so that the learning objectives optimally can be achieved. And the strategy is chosen after the teachers know the characteristic of materials and students, in order to achieve the learning objectives maximally.

$$
\text { A learning strategy might is }
$$

one of the most effective instructional techniques for students with learning problems, strategy instruction is often crucial for students' success. (Reid, R., \& Lienemann, T.O, 2006) Strategies are able to provide long-term direction to achieve the target that will be addressed and creating learning systems to be more effective, as well as a barometer of the learning progress. This statement is in accordance with what hall says related to language learning that "the most important teacher role in teaching is the provision of a range of tasks to match varied learning styles" (Hall 1997:4). 
The above statement means that teaching and learning strategy is very important to be used, especially for teachers who have responsibility to the students' learning objective. However, the main learning problem in university mostly is how the lecturers' planning and readiness to manage learning which be able to achieve the students' competences.

Preparing students to become PAI professional teachers, STIT al Urwatul Wutsqo has conducted teaching and learning strategy as one of its subject. The students, however, could not catch the material, even; they did not understand the concept of learning strategy, since the learning process always used presentation method in which only few students who actively involved in the teaching and learning process, with only a little understanding of the matter concept, the rests got nothing.

The unfamiliarity evidence can be seen when they implemented micro teaching, they knew and practiced lecturing method only. After non-formal interviewing about their inability to implement the methods and learning strategies, seemed the lecturers in teaching used presentation and question answers which made them could not find the concept of learning strategy subject. It means the teaching and learning process, especially the learning strategy course has problem needs to overcome. One of the ways is changing the teaching method.

There are many teaching method can be implemented to improve teaching quality. One of them is practice method. is considered as an instructions of the Quran and Sunnah in the form of real action. Muslim educators of course, must pay attention to the development of attitudes and understanding that the students' progress is closely related with training and experience they face. Besides, they also must show their acts and practices what they have learned in their real life, so they can find the clarity between theory and practice.

The subject which needs skill should be practiced; the students cannot touch by their shadow, when it is done the learning objective will not be achieved. They need concrete examples. Because not all students are able to capture something abstract, even if they can, the practice is better.

The holly Qur'an of al-Kahf: 66-73 verse, explains that Moses prophet experience when he was studying to the prophet Khidr. The story described the direct practice as an educational effort that was how Moses had to practice patience in receiving an education from the prophet Khidr. It means that practice method has been done since Moses prophet era.

According to Pupuh, practice method is methods that provides better educational materials either using tools or objects, such as in the act out, with purpose of making students clearly and easily understand and they can practice the subject material they have gotten. (Pupuh Fathurrahman dan Sobry Sutikno, 2007, p.64) In lain with Pupuh, Simanjutak explains that practice method provides a way for participants to apply, train and ad very good experience to develop and refine their skills needed.(Simanjuntak, 1983, p.29)

Edwardes stated that practice learning process involved three 
phases, namely teacher presentation. Students' practical activities, and the learner's assessment performance. (Edwardes, HN, 1983, p.65) However, in this case the researcher, before practicing the method, explained the concept, steps, and showed the examples. It is used to make the students can catch the material easily.

Practice method is a teaching method in which students conducting practical exercises so they have the higher skills of what have learned. Direct practice as an educational experience involving students actively involved of the object manipulation to increase the experience. (Haury, D.L \& Rillero, p, 1994) In STIT al Urwatul Wutsqo, the lecturer has practiced as model, and then it is followed by students with different models they have got.

The principles of learning practice are; involving the students' sense by doing self activity; practicing to improve their interest; mastering the material practice correctly. (Daryanto, 2009, p.410) By the principles the teachers are required to prepare their students to master the subject both theoretically and practically. Besides, the students are given the opportunity to improve their creativity. It shows that practical method in teaching learning process is better.

The advantage of practice method are: acquiring the students' motor skill, such as sound out words or sentences, making the tools and motion; getting mental skills, such as in the multiplication, summing, subtraction; gaining proficiency in the form of associations made, such as the relationship of letters in spelling, use symbols, reading map; Causing habit, adding quick and accuracy of the implementation; utilizing the habit without require concentration in practice; The complex movements become more automated. Besides, it increases students' motivation and passion for the work performed provides a new challenge.(Syaiful Bahri Djamarah dan Azwan Zain, 2002, p.96)

Related to motivation, practice method will increase the student's motivation because this method involve students to be very active, besides, they can practice themselves and they are free to improve their creativity in teaching practice. Practice method is part of demonstration.

Motivation is the driving force within the students who lead learning activities, and ensure the continuity learning activities as well as directions on learning activities. (Sardiman, 2008, p.75) This statement shows that motivation is very important especially to give effect students in the teaching and learning process. And demonstration or practice method can be one of the ways to increase students' motivation.

Demonstration method is a method of teaching by way of demonstrating items, events, rules, and the order to do an activity, either directly or through the use of teaching aids that are relevant to subject or the material being presented. This method will be useless when the students are not involved in practicing, that is why the researcher asked the students to practice the material especially related to the learning strategy and model to be practiced directly in front of their friends.

Practice method is an effort to provide students' opportunities to 
gain direct experience. The teacher does not only give instructions and explains the material in front of the class, but these activities can be done together, namely direct practice. And the nature of practice methods can trigger the development of students' skills to be more creative.

The research results related to practice method are done by Nur Chasanah, et al. They said that the results showed that the students' ability in conducting health promotion is highly increased. They then explained that this method is appropriate in increasing the students' psychomotor, since it gives a real experience to the learners. Finally they suggested using practice method at university, as it can improve the course achievement. (Nur Chasanah, et.al, Jurnal Ilmiah Keperawatan Volume 2 No.1 Maret 2016)

\section{Method}

This research design is qualitative research which has been conducted for four months. The object of this research was the third semester of academic year 20172018. This research was implemented in three classes that were $\mathrm{C}, \mathrm{D}$, and $\mathrm{E}$, since the researcher was teaching at those classes. This research used four procedures proposed by Spradley 1980 , namely determining the social situation, participation observation, making field notes, and descriptive observation ${ }^{1}$.

\footnotetext{
${ }^{1}$ Spradley, James. Participant Observation. (terj.). Edisi Kedua. (Yogyakarta: Tiara Wacana), 1980.
}

The research as focused on the teaching and learning process using practice method. The purpose of this research to know wither or not teaching learning strategy using practice method is effective, how the effectiveness of that method. To achieve the goal, the researcher used observation checklist, questioner, interview and documentation as research instruments.

This research was conducted when the researcher taught at that class. In this case the researcher is teaching subject of learning strategy using practice method. The procedure of teaching were, the researcher taught and explained the material for about four times. After that the researcher practice using methods had been explained. Te students listened to and understand the concept of material. The next meeting the students practice teaching religion material using practice method.

In practicing the teaching, the students are grouped, and each of group was three or two members. Before the implementation of learning they conducted, they had to prepare lesson plan in group; however, the lesson plan might be different in a group. The lecturer also accompanied them in preparing lesson plan, such as corrected them or giving suggestion, etc.

\section{Finding}

\section{The Result of Observation}

The researcher in observing the practice method used some teaching indicators, namely; the students' preparation; teaching practice; working cooperatively; students' difficulties in practicing models of 
learning, the student's
involvement and learning evaluation. The observation was done at September to December 2016 are as follows:

a. The students' preparation

Before starting to practice, the students had to prepare sets of learning, in this case the lecturer only asked them lesson plan. The students looked for the sample of lesson plan from Islamic religion teachers with free materials. They had learnt before practicing. When they practiced teaching, the lesson plan was submitted to the lecturer or other group to be evaluated whether or not they practice teaching based on the lesson plan.

b. The teaching practice

After the lecturer as researcher opened the lesson, the lecturer asked students to start teaching based on the group order. The group and its member came forward and performed one by one. Before they practiced they gave the lesson plan to the lecturer and other group to be evaluated. The other group evaluated the participant's teaching based on the lesson plan. Their note had to be written on the paper and submitted to the lecturer afterward, the other group was also given opportunity to give comment and suggestion about the participant performance freely. The other groups were forbidden to give questions to the participant, however. This is to minimize the time. Since each participant was only given around fifteen minutes to perform. Besides, the participant is considered new students, so it was done to avoid their uncertainty in practicing teaching.

The implementation of learning using practice method was very effective, because almost all the participants were actively involved in the learning process. When one of the member groups practiced of teaching, the other group listened carefully while concentrated to the lesson plan they hold. The other members were busy to write down the note.

In practicing learning models, the students, especially D class mostly practiced well. They could teach confidently. When they made mistake, they continued their teaching without indicating if they left one or two steps of their lesson plan. This way can cover their deficiency.

The teaching and learning process was done well for all classes, because most of students especially the D class could teach as teacher, because they practiced and evaluated by the class before practicing in front of the lecturer, and their weaknesses had been corrected by their friend, so they could practice smoothly in front of the researcher as lecturer.

Some interesting things have been done by students, such as some students used media to teach their material; they could improve their learning model used; they used varied learning models, and some of them combined some learning models. 
c. Cooperative in group

Most of students could work cooperatively in group. It can be seen from their compactness when they were practicing learning models. Most of the practitioners could practice well. When one of the member practice the model, the other members help each other, for example the third group of B class who forgot the material, then some member of that group reminded directly. It was done because the compactness is also included in the assessment of practicing method. The teaching devices also supported their cooperation.

d. The students' difficulties

The students' difficulties mostly about the Islamic religious education materials, it is understandable, because they have not mastered the material. The indicators' development in the learning aim is also one of the students' difficulties. The students in practicing the learning model were only based on teaching procedure and how they taught well. The student who practiced learning model by implementing the same materials also got difficulty in managing the class, because the audience who were their class mate was bored listening the same material and same model moreover.

e. Evaluation.

The students in evaluating their learning practice both individuals and groups was orally or written test, and they did with very simple, for instance, they asked some questions related the material given, the noted the score. In written test, they distributed paper of test, and then asked their students to do well, finally they submitted the result. This is understandable because they do not get the learning evaluation subject.

f. Students' involvement

The students' involvement of three classes is one of the evidence to the effectiveness of practice method. They were mostly actively involved in the teaching and learning process, especially when those who practiced used an interesting method. The audiences were watching and commenting on their practices. Though the practitioner was only in a group, they helped each other to get the good score.

The students did not only listen and correct the group mistakes, but they also learned from their friends' superiority and weaknesses. It can be said that they could get more knowledge about teaching and learning.

The excellence gained by students is about how they estimated their friends 'performance, in this case the students could give score accurately. It was not different so far from the lecturer.

The students' involvement is also related to their comment of their friends' performance. They could give good comment to increase their appearance. The comments will be practiced by the 
following participant. So the students' performance the more the better.

\section{The Result of Questionnaire}

There are six statements from the questionnaire, namely students' liking, feeling, involvement, motivation, students' effect to their ability and their opinion about the implementation of the strategy.

The results of questionnaire are as follows:

The students' like explain that from 70 students, 50 students (71, $5 \%)$ like this method very much, 16 students $(22,8 \%)$ stated that they like, and 4 students (5.7\%) dislike this method and none of them dislike very much. Related to students' feeling about the implementation of practice method is 45 students $(64,3 \%)$ they were very satisfied with the method, 20 students $(28,6 \%)$ were satisfied, and 3 students $(4,3 \%)$ were not satisfied, and 2 students $(2,8 \%)$ were not satisfied very much.

The most students were involved in the teaching and learning process. Based on the result of questionnaire about the students' perception of their involvement is 60 students $(85,8 \%)$ said that they were actively involved from preparing to implementing, 5 students $(7,1 \%)$ said that they were involved in the preparing without implementing, and 5 students $(7,1 \%)$ said that they were not involved either in planning or implementing.

The students' statement about their motivation can be seen from result of the questionnaire which said that out of 70 students who joined the practice method, it is known that 56 students $(80 \%)$ were motivated very much, 10 students $(14,3 \%)$ stated that they were motivated because of the method, and only $4 \quad(5,7 \%)$ students who were less motivated with the method, however, none said that they were not motivated very much.

There were $40 \quad(57 \%)$ students who stated that their ability about the concept of model and learning strategy is absolutely increasing, then 20 students $(28,6 \%)$ said that ability increase, 4 students $(5,7 \%)$ said that their ability neither increasing nor decreasing, and 6 students $(8,7 \%)$ complained that their ability became decreasing.

Meanwhile the students' opinion about the method was 60 students $(85,8 \%)$ they agreed very much with the method, 8 students $(11,4 \%)$ they agreed, and 2 students $(2,8 \%)$ disagreed, and none disagreed very much with the method.

\section{The Result of Interview}

After implementing the practice method, the researcher interviewed more than ten students asking their opinion about the teaching learning process through practice method. Their answers were that they were interested and motivated in the method. they said that practice method can be applied to prepare them in learning teaching.

Before practicing this method, many students said that lecturing is the most appropriate method to teach university students because they were given opportunity to ask and answer the questions. Besides, the students 
can increase their capability to speak up, since speaking is very difficult, even they are the candidate of teacher. So learning to speak is very important. However, after they found the practice method, they said that practice method is more effective to provide students as teachers' candidate to be professional one.

As Putris' answer that was translated to English, "she liked so much with the method, because it can become provision when she is a teacher". Her opinion is also supported by Zuria, she said that this method is better than she and her friends made presentation as usual".

In line with them, Zidan said that "he never used that method, since he actually liked to listen to the lecturer, however, after he did practice, he wants all subject is practiced". There are many opinions related to the teaching and learning using practice method, however, the three opinions have represented their opinion.

One of students of $\mathrm{C}$ class explained, practice method can eliminate the laziness has tended she experienced, by practicing methods she prepared seriously because it will be performed in front of her friends and lecturer. As her explanation that she was very scared about practice method, after doing seriously she could eliminate her laziness.

Many students gave good comments about the application of practice methods, there are some students who also comments that do not support this method, however. For example Aan and Ulin who said that "they felt tense when requested to become a teacher, although they had prepare everything well". Nevertheless, more students who accepted this method and recommended to be implemented especially to the subject related to teaching.

\section{The Result of Documentation}

The documentation is about the students' score of the implementation of practice method. They are seventy students from three classes; every class was divided in groups. Each group consisted of four or three members. The c class is consisted of 32 students, so it was divided in 8 groups. The $\mathrm{D}$ class is consisted of 20 students, that is why this class had only 5 groups. Meanwhile E class was divided in 7 groups since the class has 28 members. The result of students score in practicing the method can be seen from the following table.

Table 1.1 The Students Score Of C Class In Practicing Method In Group

\begin{tabular}{|l|l|l|l|}
\hline $\begin{array}{l}\text { GRO } \\
\text { UP }\end{array}$ & $\begin{array}{l}\text { Peer } \\
\text { Evaluati } \\
\text { on }\end{array}$ & $\begin{array}{l}\text { Lecturer } \\
\text { evaluati } \\
\text { on }\end{array}$ & $\begin{array}{l}\text { Tot } \\
\text { al } \\
\text { scor } \\
\text { e }\end{array}$ \\
\hline I & 86,57 & 80,4 & $\begin{array}{l}83 . \\
5\end{array}$ \\
\hline II & 85,80 & 81,1 & $\begin{array}{l}83 . \\
5\end{array}$ \\
\hline III & 90,54 & 90,2 & $\begin{array}{l}90 . \\
4\end{array}$ \\
\hline IV & 92,75 & 90,5 & $\begin{array}{l}91 . \\
6\end{array}$ \\
\hline V & 78,34 & 75,7 & 77 \\
\hline VI & 90,45 & 87,89 & $\begin{array}{l}89 . \\
2\end{array}$ \\
\hline VII & 91,42 & 90,75 & $\begin{array}{l}91 . \\
1\end{array}$ \\
\hline VIII & 93,5 & 90,1 & $\begin{array}{l}91 . \\
8\end{array}$ \\
\hline
\end{tabular}


Table 1.2 The Students Score Of D Class In Practicing Method In Group

\begin{tabular}{|l|l|l|l|}
\hline $\begin{array}{l}\text { GRO } \\
\text { UP }\end{array}$ & $\begin{array}{l}\text { Peer } \\
\text { Evaluati } \\
\text { on }\end{array}$ & $\begin{array}{l}\text { Lecturer } \\
\text { evaluati } \\
\text { on }\end{array}$ & $\begin{array}{l}\text { Tot } \\
\text { al } \\
\text { scor } \\
\text { e }\end{array}$ \\
\hline I & 92,27 & 90,1 & $\begin{array}{l}91 . \\
2\end{array}$ \\
\hline II & 95,80 & 95,0 & $\begin{array}{l}95 . \\
4\end{array}$ \\
\hline III & 94,75 & 93,4 & $\begin{array}{l}94 . \\
1\end{array}$ \\
\hline IV & 96,75 & 95,5 & $\begin{array}{l}96 . \\
1\end{array}$ \\
\hline V & 96,34 & 94,70 & $\begin{array}{l}95 . \\
5\end{array}$ \\
\hline
\end{tabular}

Table 1.3 The Students Score Of E Class In Practicing Method In Group

\begin{tabular}{|l|l|l|l|}
\hline $\begin{array}{l}\text { GRO } \\
\text { UP }\end{array}$ & $\begin{array}{l}\text { Peer } \\
\text { Evaluati } \\
\text { on }\end{array}$ & $\begin{array}{l}\text { Lecturer } \\
\text { evaluati } \\
\text { on }\end{array}$ & $\begin{array}{l}\text { Tot } \\
\text { al } \\
\text { scor } \\
\text { e }\end{array}$ \\
\hline I & 84,40 & 78,2 & $\begin{array}{l}81 . \\
3\end{array}$ \\
\hline II & 85,20 & 78,3 & $\begin{array}{l}81 . \\
8\end{array}$ \\
\hline III & 91,4 & 90,0 & $\begin{array}{l}90 . \\
7\end{array}$ \\
\hline IV & 90,5 & 78,3 & $\begin{array}{l}84 . \\
4\end{array}$ \\
\hline V & 80,50 & 75,2 & $\begin{array}{l}77 . \\
8\end{array}$ \\
\hline VI & 90,0 & 87,8 & $\begin{array}{l}88 . \\
9\end{array}$ \\
\hline VII & 88,30 & 85,7 & 87 \\
\hline
\end{tabular}

\section{Discussion}

The result of observation shows that the implementation of practice method in teaching model and strategy learning is very effective. It can be seen from their sets of learning. All groups had submitted the learning set before practicing. The first learning set was of course needed to be repaired because it had many mistakes. After the lecturer gave comments about it, all students in group corrected based on the lecturers' suggestion. So the following learning sets were better.

The teaching practice was conducted effectively, since the students mostly practiced well. They could teach confidently their mistake could be covered by their confidence, it can be said that they had tried to teach as like real teacher. However, few students still had mistakes in their performance. Besides, the students were able to improve their learning model by combining some steps of learning models.

Most of students could work cooperatively in group. For example when one of the members practiced the model, the other members help each other, then some member of that group reminded directly. The researcher realizes that to be compactness is difficult, so the compactness was included in the assessment of practicing method.

The students' difficulties was about the Islamic religious education materials, the indicators' development in the learning aim, and the same material in practicing is also make the get difficulties in managing the class. In evaluating, most of the used written and oral test, they listened and corrected the group mistakes, learned from their friends' superiority and weaknesses, so it is more knowledge for them about teaching and learning, they also could give score accurately. The students in the teaching and learning process were able to give good comment to their friends' performance, and the comments will be practiced by the following participant, so the implementation of 
practice method can be said is very effective.

The result of questionnaire showed that most of students were interested in learning process using practice method. Their interesting can be seen from their option of answer, which is mostly the first one was chosen by the students, so they got four score from each question.

The data was $71,5 \%$ the students like the method very much, $64,3 \%$ they were very satisfied, $85,8 \%$ they were actively involved, $80 \%$ they were motivated by the method, 57\% the students ability of the learning strategy subject increased, and $85,8 \%$ they agreed if the practice method is implemented.

The result of interview showed that most of students gave good comment about the implementation of practice method, such as they like very much, they wanted the method is practiced to all subject, and the method can eliminate their laziness.

The document result explains that the highest score is 96,1 and the lowest score is 77,0 . It can be concluded that the teaching learning strategy subject through practice method can support the ability of mastering the material and teaching skill. It means that the result of observation, questionnaire, interview and documentation is not so far, even, they support each other.

The above finding is appropriate with Pupuh that practice method is methods which provides better educational materials either using tools or objects, such as in the act out, with purpose of making students clearly and easily understand and they can practice the subject material they have gotten. In this case the students can practice the method they have gotten to practiced in front of the class.

Meanwhile the explanation of Simanjutak that practice method provides a way for participants to apply, train and ad very good experience to develop and refine their skills needed. By practice the students will get real experience in teaching in front of the class. Besides, practice method is: acquiring the students' motor skill and increases students' motivation and passion for the work performed provides a new challenge. It can be showed by the increasing of student's motivation based on the observation and interview result.

\section{Conclusion and Suggestion}

The result of the research is about the teaching learning strategy subject using practice method is very effective. The effectiveness of the method can be seen from the result of observation that most of students were actively involved in the teaching and learning process. The questionnaire is supported the effectiveness, since most of students chose positive answer which supported the implementation of practice method. the result of interview and documentation also showed positive responses of the method and the gaining of good score. So it can be concluded that implementing practice method in teaching learning strategy to prepare students to be professional teacher is very effective. 


\section{References}

Clearinghouse for Science, Mathematics, and Environment Education, 1994

Daryanto, 2009, Panduan Proses Pembelajaran, Jakarta: Publiser

Edwardes, HN, 1983, Bagaimana Membantu Orang Belajar Ketrampilan, Padang: FPTK. IKIP Padang

Hall, Stephen. 1977, Language Learning Strategies: from the ideals to classroom tasks". Language and Communication Division, Temasek Polytechnic on Internet. .

Haury, D.L \& Rillero, p. 2006, Perspective of Hands-On Science Teaching, Columbus, OH: ERIC Kencana Prenada Media Group

Nur Chasanah, et.al. Penerapan Metode Praktik Untuk Meningkatkan Kemampuan Melaksanakan Promosi Kesehatan Jurnal Ilmiah Keperawatan Volume 2 No.1 Maret 2016.

O'Malley, J. M. \& Chamot, A. U. 1990, Learning strategies in second language acquisition, Cambridge: Cambridge University Press

Pupuh Fathurrahman dan Sobry Sutikno, 2007, Strategi Belajar Mengajar. Bandung: PT Refika Aditama

Reid, R., \& Lienemann, T.O. 2006, Strategy instruction for students with learning disabilities: What works for special needs learners? New York, NY: Gilford Publications

Richards, J. And John Platt. 1922, Longman Dictionary of
Language Teaching And Applied Linguistics. Essex: Longman

Sardiman, 2008, Interaksi dan Motivasi Belajar

Mengajar, Bandung, Rajawali Pers

Simanjuntak, 1983, Proses Belajar Mengajar, Bandung: PT Tarsito

Spradley, James. 1980, Participant Observation. (terj.), Edisi Kedua, Yogyakarta: Tiara Wacana

Syaiful Bahri Djamarah dan Azwan Zain, 2002, Strategi Belajar Mengajar

Wina Sanjaya, Strategi Pembelajaran Berorientasi Standar Proses Pendidikan (Jakarta : cet. 